\title{
Determinants of Policy Diffusion in Brazil and the
} U.S.

Denilson Bandeira Coêlho

\section{(2) OpenEdition \\ Journals}

Electronic version

URL: https://journals.openedition.org/irpp/2254

DOI: 10.4000/irpp.2254

ISSN: 2706-6274

Publisher

International Public Policy Association

\section{Printed version}

Date of publication: 30 October 2021

Number of pages: 194-215

ISSN: 2679-3873

\section{Electronic reference}

Denilson Bandeira Coêlho, "Determinants of Policy Diffusion in Brazil and the U.S.", International Review of Public Policy [Online], 3:2 | 2021, Online since 20 October 2021, connection on 17 December 2021. URL: http://journals.openedition.org/irpp/2254 ; DOI: https://doi.org/10.4000/irpp.2254

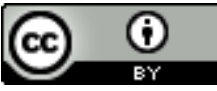




\section{Determinants of Policy Diffusion in Brazil and the U.S.}

\section{Denilson Bandeira Coêlho}

Universidade de Brasilia, Brazil

\section{Abstract}

This paper comparatively examines two highly decentralized federations, namely Brazil and the United States (U.S.) The study uses a combination of methods to determine which mechanisms explain the spread of metropolitan regions (Brazil) and the growth of the statewide smoking ban (U.S.) among state governments over the 1990s and 2000s. It uses Weibull distribution and Cox regression to measure the time until events occur and to estimate the influence of a variety of factors on the likelihood of two policies being adopted. I find evidence of electoral-year drive policy diffusion in both countries. In Brazil, a key structural variable associated with internal determinants stimulated metropolitan policy adoptions. In the U.S., structural factors - linked with citizen ideology - enhance the probability of enacting smoke-free laws.

\section{Keywords}

policy diffusion, political behavior, survival analysis, metropolitan region, anti-smoking law 


\section{Introduction}

In recent decades, federal systems have increased the number and strengthened the design of public policies. In this context, the autonomy of subnational governments, the network, and bureaucratic learning are key components. The emulation of innovation was first observed by Walker (1969) in a comparative analysis among American states. Since the 1990s, the agendasetting has changed from a static and endogenous event to a dynamic and exogenous process. In most countries, the spheres of government became more active in terms of the formulation and implementation of institutional innovations. However, beyond legislative and executive actions, another alternative to the adoption of policies took place, i.e., the citizenship initiative, bureaucracy proposals, and state court decisions. Democratic laboratories ${ }^{1}$ disseminated new ideas that influenced the distribution of public goods and political behavior by policymakers, citizens, and leaderships. However, why do the phenomena of adoption among governments occur frequently in some countries and not in others? To answer the question, I focus on two cooperative and competitive federalist countries that are highly decentralized in terms of public administration, namely Brazil and the U.S.

The literature of policy diffusion focuses on innovative political governments and on how it has influenced the adoption of new policy models from other governments. In Brazil, the Federal Constitution of 1988 recognized states and municipalities as autonomous jurisdictions, giving them the right to decide to adopt their own policies and to adhere to, or reject, policies from central government. Brazilian political science has made a minimal contribution to horizontal policy diffusion across subnational governments. The few studies have a focus on: intergovernmental relations, innovation of public administration and local initiatives (Farah, 2008a, 2008b); adoption of governmental professional careers (Palotti et al., 2016); interstate cooperation (Abrucio et al., 2016); conditional cash transfers (Sugiyama, 2008; Coêlho, 2012a, 2012b); participation and social control (Wampler, 2008; Porto de Oliveira, 2016); health and education (Sugiyama, 2007; Coêlho et al., 2016; Segatto, 2018); vertical and horizontal diffusion of constitution norms (Couto \& Absher-Bellon, 2018); and the spread of metropolitan regions in Brazil (Fernandes et al., 2019). In the U.S., state constitutions ${ }^{2}$ give autonomy to the states to define the portfolio of public policies, and this is a central theme in the literature of policy diffusion, which has investigated a large group of policies in different areas.

Nevertheless, besides comprehension of the American cluster, in other countries, a comparative research agenda remains marginally settled. Researchers from Brazil have taken the central government as a unit of analysis without considering that some policies come from cities and state governments. So, in a broad sense, the literature has no systematic understanding of determinants of adoption among the spheres of government. Besides, we know little about whether the mechanisms that explain political behavior in the U.S. may similarly influence politicians, bureaucracy, and policy advocates in other countries. So, there are many cases to be explored, which remain unexamined comparatively. To test the theories of policy diffusion and its methodological approaches, I selected two different major topics: urban areas in Brazil and the health sector in the U.S. I focus on Brazilian metropolitan regions and on anti-smoking laws in the American states. Several considerations drive my choice of policies. First, since the 1990s, these are the two areas that have the highest score innovations and spread effects. Second, the diffusion took place horizontally among states; in other words, without the participation of the federal government. Third, in both cases, there was a lag time between the first and subsequent adoptions.

1 - Creative and innovative governments that have experienced new public policies (Karch, 2007).

2 - State constitutions were established at the end of the 1700s and during the 1800s (Clouse, 2019). 
The central argument of this study is that, while both countries have remarkable distinctions between state governments, nonetheless specific innovations may influence similar political behavior and institutions. A secondary argument speculates on the effect of preview policies and structural factors, which would strongly influence policy diffusion in the U.S., but not in Brazil. To explore the determinants of the metropolitan region and statewide smoking-ban diffusion, I utilize a comprehensive database of laws passed between 1991 and 2018 across Brazilian states and anti-smoking laws enacted from 1995 up to 2010 among American states. The results of the analyses contribute to the understanding of patterns of policy diffusion in both countries. First, I show that institutional trajectories do matter when explaining differences in political behavior. Second, I show that uncoordinated action also produces distinct institutional effects. In Brazil, the state's politics are influenced by its local agenda. In the U.S., the regional and national agenda prevails due to the interconnectedness of the states.

In the following section, a literature review and the theoretical elements explored are described to test the hypotheses of the study. Next, I describe the policy diffusion context, with an emphasis on the attributes of each case. I then turn to the methodological section to explore the statistical models and the databases. I then analyze the results and I conclude by highlighting a discussion in which I compare the empirical findings and the theoretical implication for future research with a focus on the federal system.

\section{Policy Diffusion Theory and Hypotheses}

After 50 years of studies, the central questions of policy diffusion literature continue to be explored. Why do some governments adopt innovative policies while others do not? Which factors explain horizontal and vertical diffusion? Walker's (1969) seminal work shed light on the puzzle of policy diffusion with an emphasis on regional clustering. This work measured adoption by the number of geographically neighboring states that had already adopted the given policy (Shipan \& Volden, 2012), offering a starting point to scholars developing an interdisciplinary analysis with a focus on political behavior and federalism studies ${ }^{3}$. Thus, traditionally, policy diffusion investigations focus little on the quality and evaluation of public policies in exploring how the political system adopts an institutional innovation. In political science, policy diffusion studies put broad emphases on multiple agenda-setting in a relatively short period. As previously demonstrated by Berry and Berry (1990), when analyzing the state lottery adoption, and by Mintrom (1997a), regarding the case of school choice, the innovations change the trajectory of policies, and the innovative states influence non-creative states. As mostly discussed, these influential studies are unified in the same theoretical-methodological construct factors associated with internal and external determinants. The application of the survival analysis statistical model grouped internal factors, such as political competition, ideology, institutional capacity, and economic indicators, with external factors such as the network, geographic proximity, and intergovernmental competition.

From this perspective, diffusion scholars started to demonstrate that the trajectory of policies was interrupted not only by critical junctures. Consistent literature has examined other mechanisms that drive policy diffusion, which include learning, emulation, competition, and coercion (Karch, 2007; Shipan \& Volden, 2008; Gilardi, 2010; Gilardi \& Wasserfallen, 2019). The mechanism of learning occurs when there is a replication of instrument constituency and

3 - From this study, other theoretical and empirical collaborations emerged in the areas of educational innovation, social security, and the environment (Gray, 1973; Collier \& Messick, 1975, Menzel \& Feller, 1977). 
when states realize that they could benefit (Volden, Ting \& Carpenter, 2008) ${ }^{4}$. Emulation takes place when the ideas are borrowed because some states follow other states' leads and adapt the policies to local reality. Competition is a dispute between attractions of economic investment and fiscal adjustment for stability and growth. Still, as indicated by Boehmke and Witmer (2004), it leads either to positive or negative cycles. Coercion means that governments are pressed to adopt a policy through a counterpart and with little space for bargains. Other works have demonstrated the importance of policy advocates, political entrepreneurs, and social organizations as crucial elements to the adoption of innovations (Balla, 2001; Mintrom, 1997b). Graham et al. (2013), in a systematic review of the literature, show how policy diffusion scholars have connected their theoretical and methodological approaches with other subfields such as American Politics, Comparative Politics, and International Relations. The authors claim that there are different dimensions to developing a policy diffusion investigation. One of these is focusing on policymakers as key actors in supporting innovation, diffusing policies, and acting between governments and social networks. This is a central question with the potential to impact positively or negatively on the diffusion of norms and instrument constituencies. From this perspective, internal actors play a central role in approving or rejecting the socialization process of their states. Another dimension is the nature of policy diffusion, and which external actors are involved in the process. The argument is that a group of governments follow the leader due to their preview portfolio of successful policies and attributes such as economic development. Recent studies have explored the role of the federal government, and the interpretation of federal and state constitutions since policies involve a set of rules and jurisdictions which may result in litigation (Strebel, 2011; Karch, 2012; Hinkle, 2015).

In an overview, the policy diffusion framework is highly distinct from a traditional study of agenda-setting. Research in policy diffusion should define the hypothesis associated with interdependence between governmental units considering that the preview adoption affects subsequent adoption (Strang, 1991). Other attributes that reinforce the distinction of the diffusion phenomena include: the time variable, since the adoption is systematic and fragmented for medium and long periods; the identification of geographic clusters; federalism designs; party composition; and networks (Coêlho, 2016). These waves may originate through local democratic experiences, through policy transfer, or through emulation. According to Elkins and Simmons (2005), diffusion is characterized by interdependent but uncoordinated decision-making. My hypotheses were defined based on theoretical support from the literature and they follow the epistemological basis of the field of studies. Although the two phenomena are from distinct areas, the supposition is that the motivation to adopt both urban and anti-smoking policies occurs due to the high costs of maintaining the status quo of systems in which these policies are inserted. I focus here on two issues that are crucial to understanding the spread effect: political pressures and the structural factors of each policy.

Following the literature, the hypotheses combine internal and external determinants. First, I argue that political actors have the motivation to adopt innovations in a competitive political environment, to reach a positive evaluation from voters, and then to guarantee political survival (Baybeck et al., 2011; Coêlho, 2012a). Also, scholars have shown that the adoption of new policies allows politicians to credit claims (Keefer \& Khemani, 2003, 2005). The electoral incentives are also tested, taking as a parameter the exact correspondence of time amongst political behavior and elections. Agreeing to seminal studies, I consider that electoral connection

4 - Some studies consider their own adoption as a learning process. This view has been criticized because it does not have elements to be evaluated, such as level of institutional impact, effects on bureaucratic organization, and indicators of policies. Regarding bounded learning, see Meseguer \& Gilardi (2009). 
increases the political will in adopting innovation as a strategy to influence voters positively (Kiewiet \& McCubbins, 1985; Berry \& Berry, 1992). There is a broad literature addressing the impact of political parties on policy innovation. Following preview studies, I include variables to check the influence of some characteristics of the party system regarding policy diffusion (Berry et al., 1998; Coêlho et al., 2016). Once metropolitan regional laws enact the integrations of public policies of social interest, such as habitation, transport, health, and education, I expect governmental activism from leftist parties as these tend to be more interventionist in passing laws. The electoral coalition is potentially an explanatory variable in the adoption of institutional innovations (Berry \& Berry, 1992; Caughey et al., 2017). The political control of the House of Representatives is fundamental to the approval of laws. Governability costs and agenda-setting approval tend to be well conducted and more cohesive according to how well aligned legislative and executive power is. So I expect that states with a high number of coalition parties, and a low effective number of parties, will be more likely to adopt new policies. The following hypotheses reflect the context that the partisan composition will affect the political behavior of legislators and governor. The first four hypotheses have drawn my primary arguments regarding the political dimension.

H1: States are more likely to adopt metropolitan regions in electoral years.

H2: The probability of adopting a law in a metropolitan region increases when the party winning the election is ideologically from the left.

H3: The higher the extension of an electoral coalition, the higher the probability of adopting metropolitan regions.

H4: The lower the effective number of parties and, consequently, the distribution of votes, the higher the probability of creating a metropolitan region.

Taking some specific aspects of the adoption of metropolitan regions, I consider that structural variables can drive diffusion. According to the Brazilian Institute of Geography and Statistics (IBGE), the creation of metropolitan regions might include at least one regional capital ${ }^{5}$ with economic and social influence from the other cities. As affirmed by Berry (1994), state policymakers are likely to be influenced by other factors internal to the state, and these factors should be controlled. Although it is not mandatory, I expect the policymakers to apply this instrument to pass the law. Otherwise, the proposition may not be passed. My fifth hypothesis summarizes this view:

H5: The regional capital increases the likelihood of adopting a metropolitan region.

The study of policy diffusion in the U.S. is theoretically driven by political incentives, structure, and network (Karck, 2007; Boushey, 2010). Based on Walker's (1969) work, I assume that states adopt policies to address local public policy issues and also to make part of a group of adopters to compete with other states for fiscal resources. Previous studies have explored why some states have adopted anti-smoking bans sooner, while other states have done this at a later date, and when the governor deems health important (Shipan \& Volden, 2006; Pacheco, 2012). Concerning these assumptions and empirical contributions, I defined a pool of hypotheses regarding statewide smoking-ban diffusion. Regarding party competition, the literature has dedicated attention to divergences between Democratic and Republican parties and how these influence the decision to innovate. The social vision of Democrats traditionally

5 - Regional capitals are urban centers with a high concentration of management activities, but with a smaller reach in terms of region of influence, compared with the metropolises. In all, 97 cities are classified as Regional Capitals across the country (IBGE, 2018). 
defends the adoption of policies with a focus on specific groups of the population, while the Republicans tend not to support these, claiming that such laws are arbitrary and restrict individual liberty (Boushey, 2014). These party attributes lead to the premises related to Democratic Party support. Scholars have considered some aspects of political competition, such as the strategically timed decision to influence the electoral behavior of voters (Berry and Berry, 1990; Karch, 2007; May, 1992). In this perspective, electoral rewards do matter to the policy diffusion process. In addition to testing the effect of political behavior, I control for other state government preferences. Berry et al. (1998), Shipan \& Volden (2006), McCann et al. (2015), and Butler \& Pereira (2018) suggest that more activist and more liberal governments are more likely to pass laws and enact smoking restrictions. In this sense, I expect that, when both legislative chambers have Democratic majorities, the most liberal government will adopt the policy. The following hypotheses capture these points:

H1: States are more likely to adopt statewide smoking-ban policies in election years.

H2: The higher the partisan composition, the higher the probability of adopting the statewide smoking-ban policy.

H3: The probability of adopting a statewide smoking-ban policy decreases when the government is ideologically conservative.

Finally, to assess a complementary view regarding the internal impact on state policy adoption, I also control by factors potentially associated with the diffusion of anti-smoking policies. First, citizen ideology is conceived to have differing support for anti-tobacco laws in the most conservative and the most liberal states. Second, the percentage of adults who smoke can influence state legislative actions (Berry et al., 2007; McCann et al., 2015; Shipan \& Volden, 2006). Following these studies, I expect that more liberal states might pass such a law because its citizens are more inclined to support collective health policies. However, in a state with a significant number of smokers, I expect the legislators to be pressured either to reject the law or to spend more time passing it.

H4: States with more liberal citizens will be more likely to adopt a statewide smokingban policy.

H5: The higher the percentual of smokers, the lesser the likelihood of either adopting the statewide smoking-ban policy or of spending more time over approving it.

Some states are influenced by the structure of the system in the way that the innovation is adopted (Pacheco \& Boushey, 2014). As stated before, scholars have shown that the governor plays a crucial role when he/she deems health to be important. Similarly, it is expected that states paying more attention to health issues will adopt preview policies, especially anti-smoking laws. The last two hypotheses highlight this conception.

H6: The preview adoption of health policies between the 1990s and 2000s increases the likelihood of adopting a statewide smoking-ban policy.

H7: Those states with anti-tobacco laws, such as government building restrictions, are more likely to adopt a statewide smoking-ban policy.

\section{Policy Diffusion in two Highly Decentralized Federations}

The attributes of public policies themselves matter in explaining policy diffusion (Makse \& Volden, 2011; Shipan \& Volden, 2012). While in Brazil the institutional arrangement of law is complex because it involves a pool of rules and governments, in the U.S. it is also complex since 
is designed to monitor social behavior and to regulate the tobacco industry. Nevertheless, the potential obstacles to policies were overcome by their key attributes, and the two innovations spread over time. In the Brazilian case, since 1989, through complementary constitutional laws, the jurisdiction for adopting metropolitan regions was given to the state's government ${ }^{6}$. The metropolitan regions aim to implement regional and urban planning to improve the quality of life of citizens. They are formed by a group of municipalities with certain characteristics: geographic proximity, a large population, social and economic integration, and a common interest in developing the territory in terms of a transport system, habitation and basic sanitation, and protection of the environment. In the case of the U.S., the goal of a statewide smoking ban is to prohibit the smoking of tobacco products in all enclosed places and workplaces, including public buildings, and all outdoor dining areas, bars, and restaurants. The law also bans smoking in state-owned vehicles and in the presence of a minor (18 years or younger). The anti-smoking bills have some exceptions and vary between states. For instance, if practicable, the legislation permits a designated smoking area at gaming clubs, bars, and tavernas. In this situation, the local health and environment agency might adopt prescribed standards for reducing employee exposure to environmental tobacco smoke.

The hypotheses presented above are mostly explored by the studies with a focus on American politics. I argue that the premises are general and cover different areas and political systems to explore a comparison between Brazil and the U.S. The study defines some key features potentially affecting the likelihood of passing innovative laws. In other words, political parties, politicians, government institutions, interest groups, and populations act within a similar system of rules, which permits them to create and adopt policy innovation. The method of comparison is structured around three factors: federalism, the party system, and interdependence between governments. Both American and Brazilian federalism constitutionally recognizes state governments as autonomous in relation to the central government. This institutional design allows sub-national governments to disseminate public management practices among themselves. As a result, even with some distinctions, federalism acts similarly in both countries ${ }^{7}$.

In terms of the party system, the two units are very different. In Brazil, elections are held in a multiparty system (33 parties), while in the U.S. there are effectively only two parties. We may expect that this significant difference affects the agenda-setting process in some way. The few policy diffusion studies in Brazil show that innovation is historically concentrated on party leaders, namely in the Workers' Party (PT), the Brazilian Democratic Movement (MDB), and the Party of Brazilian Social Democracy (PSDB). In the U.S., empirical research shows a huge dispute over leadership in innovation among Democrats and Republicans. Consequently, the adoption of innovation is driven by a small group of parties. Another similarity is that several studies have shown that the political dimension strongly influences political behavior during the first years of innovations when it comes to adopting, or refusing to adopt, the policies. Additionally, other studies have shown that, after a certain period, diffusion waves have neutralized political resistance, and factors such as emulation, learning, and intergovernmental competition have determined the adoption (Mintrom, 1997a, 1997b; Mintrom \& Vergari, 1998; Sugiyama, 2007; Coêlho, 2012b; Shipan \& Volden, 2006, 2008; Volden, 2002, 2006).

6 - The first metropolitan regions were implemented in Brazil during the military regime by the federal government in 1973. In the 1980s, Brazil experienced two important events: the re-democratization process in 1985 and the Federal Constitution in 1988. Consequently, some federal laws were incorporated by state constitutions.

7 - Brazilian federalism was founded on a cooperative agreement by the Federal Constitution of 1988 . However, it presents problems of coordination, and misunderstandings in the interpretation of judicial laws and the separation of powers. US federalism was established on the basis of Madisonian democracy. It is based on a separation of powers, accountability, and checks and balances (Cf. Abrucio, 1998; Arretche, 2004, Dahl, 1989). 
Interdependence among different levels of government is a relatively common feature of the American and Brazilian political systems. The literature has empirically demonstrated that behavior changes may occur because of convergence governments. For example, in 1995, Paraná created Ecological ICMS ${ }^{8}$ and the 14 other states followed this lead. In the 1990s, states from north and south regions disputed the allocation of big companies in a phenomenon known as fiscal war. Innovative states, such as California and New York, have been systematically followed by a group of other states, showing that governments react to what other governments have enacted. The policy itself matters, but who adopts the policy initially matters too because it decides which states will follow the early adopters (Boehmke \& Skinner, 2012a).

In sum, on the one hand, the multiple agenda-setting is quite distinct between the two countries. Because American states are more similar than Brazilian states in terms of institutional capacity and economic resources, they are more innovative. On the other hand, I argue that, depending on the nature of policy and its costs and benefits, a new policy diffusion process can spread further among less similar states than states which are more similar, whatever the country. To explore the politics of policy diffusion, as proposed in this study, I focus on two different contexts to check which determinants explain the spread of metropolitan regions and statewide smoking-ban laws. In the next section, I turn to empirical analysis.

\section{Methodology}

To model how policy diffusion shapes the adoption of innovations, I constructed two original databases. These cover the period between 1991 and 2018 for the metropolitan regions and from 1995 to 2010 for statewide smoking bans. I relied on several sources to collect a variety of information. For both policies, I used an event history analysis to estimate the hazard rate for policy adoption among states. Following the literature, I assume that all states of each country are at risk of adopting the policy over time (Box-Steffensmeier, 1997). The next two subsections describe how dependent and independent variables were defined to test the hypotheses of the research.

\section{Data on Metropolitan Regions}

The analysis is conducted using a Weibull distribution, an event history model that permits the capture of the dependency between the time of failure ${ }^{9}$ for each unit. It reflects a situation where states can adopt the laws more than once, and the model inserts an aleatory effect into the rate of failure to explain in a more precise way the heterogeneity of the data ${ }^{10}$. A closer look at the distribution of the data reveals a concentration of adoption in the northeast and south regions. Some Brazilian states, such as Alagoas, Paraiba, Paraná, and Santa Catarina, legislated much more compared with other states. Figure 1 shows the Kaplan-Meier failure estimate. It reflects the number of states at risk of adopting the policy. The rate of adoption followed a continuous and deconcentrated distribution for most of the time. It took five years, or approximately until day 1500 , for the first two adoptions. The tendency is inverted when the curve reaches the 2525-day mark. From this point onwards, the curve tended to be faster. After day 7791, there was a sharp drop in adoptions and it achieved the final adoption on day 9356. The statistics show that 21 of the 26 Brazilian states adopted new metropolitan regions.

$8-$ ICMS is a state tax on the circulation of goods and services. It stimulates environmental protection by distributing revenue to subnational governments that promote forestation, conservation of ecosystems, and biodiversity.

9 - The literature of event history analyses is largely applied in health science, where it counts the time until the death of patients and defines the occurrence of an event as a failure. The studies in political science call the occurrence of an event as an adoption instead of a failure (Cf. Box-Steffensmeier, 2007).

10 - This method is used to minimize the error of inference of the covariables (Cf. Colosimo \& Giolo, 2006). 
The governments introduced 66 new laws across the states, with five states not adopting until the end of the research period, or day 10080.

Figure 1: Cumulative distribution of failure times for Metropolitan Regions, Brazil, 19912018

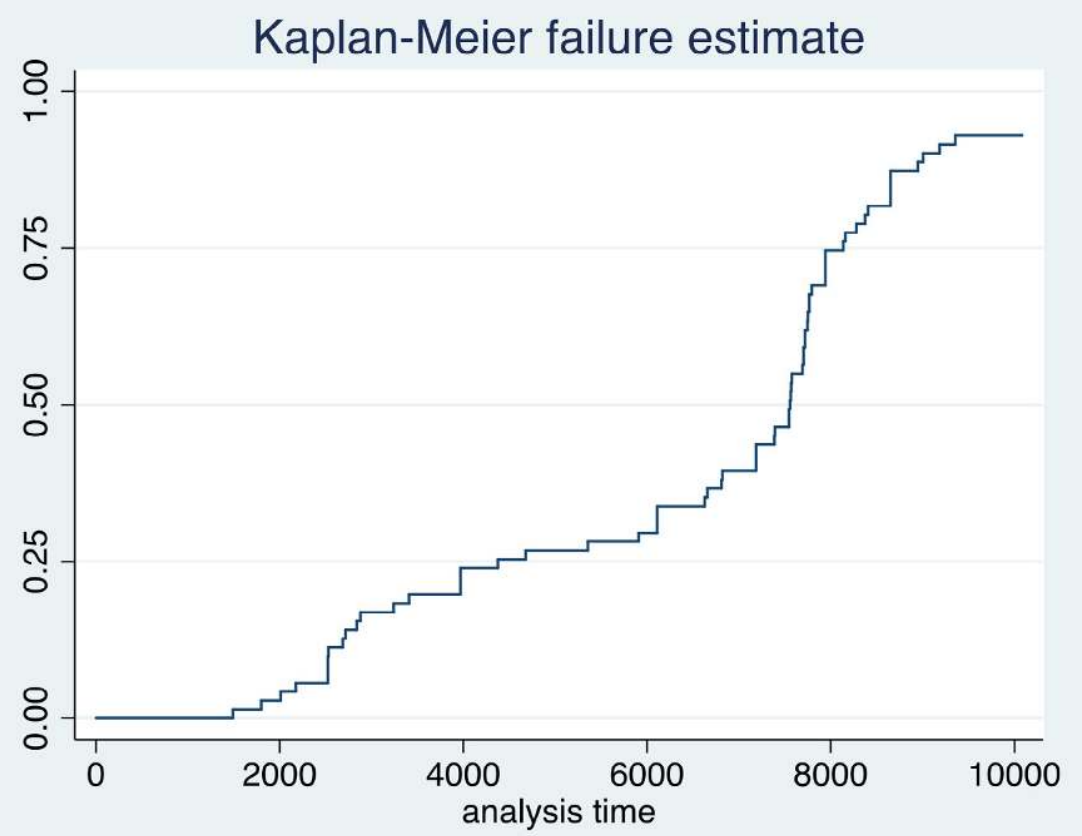

Number at risk

$$
71
$$

69

54

50

18

\section{Source: The Author}

I obtained the data for the variables from the Institute of Applied Economic Research (IPEA), the Brazilian Institute of Geography and Statistics (IBGE), the Regional Electoral Courts (TREs), and the Brazilian Legislative Surveys from Harvard Dataverse. The research assistants also collected all state laws to check the consistency of the data ${ }^{11}$. To assess the influence of independent variables on the adoption of the policy, I control for a variety of political factors and for two key structural factors, as follows.

Dependent variable. Dichotomous variable. This is the state-day-adoption and is coded 0 when the law does not pass and 1 when the law passes.

Electoral year. Dichotomous variable. This tests whether laws are adopted in the years of state elections. Once governors desire to influence the voters, I expect a positive correlation between the time of elections and adoptions. The variable is coded as value 1 for the electoral years and value 0 otherwise.

Government ideology. Continuous variable. This measures the ideological position of the governor's party. The indicator is obtained by applying a survey for the period between 1990 and 
2014 (Zucco \& Power, 2019). The indicator captures the insights of members of congress in the House of Deputies and the Federal Senate on their parties' position on the ideological spectrum. The scale varies from -1 (extreme left) to +1 (extreme right). Here there are two important observations. Because the variable is numeric and scaled and the hypothesis suggests that parties on the left are more likely to adopt the laws, I expect a significant coefficient and a positive sign ${ }^{12}$.

Extension of the electoral coalition. Numeric variable. This reflects the number of parties making up the winning coalition in state elections between 1990 and 2014. The more coalition parties, the higher the numeric indicator. I would expect a positive correlation between a strong coalition and the adoption of metropolitan regions.

The number of effective parties. Continuous variable. This measures the distribution of votes between state deputies elected between 1990 and 2014. The higher the dispersion of votes among the parties, the higher the indicator of party representation in the legislative assembly (Golosov, 2010). The scale varies from 2.9 (low distribution of votes) to 17.8 (high distribution of votes). I might expect a negative sign, while a positive coefficient would influence the adoption of the law.

Regional capital. Dichotomous variable. This reveals if the state government has, among the metropolitan region's cities, a city with regional economic and social influence, with yes equalling 1 and no equalling 0 . Laws that include regional capital are likely to be passed, so it is expected that the variable will produce a positive coefficient.

Municipal metropolitan population. In Brazil, states differ strongly in terms of institutional and social levels, economies and size. Therefore, it is critical to control for the differences between the federated states. The control variable is the log of the population. Empirical studies have shown that more populous states are more effective in adopting innovation. Thus, a positive effect is expected.

\section{Data on statewide smoking ban}

The analysis uses a standard event history logit model. I apply the Cox regression Efron method for ties due to the nature of the distribution of data. The variables were individually tested by the Schoenfeld residual method, using STATA software and the estat phtest detail function (Cleves, 2008). The results of the test show that no variables presented a deviation from the hazard proportionality assumption. The global test on the model presented a Prob > Chi2 of 0.7727. So the proportional hazard assumption is in line and the model is valid and robust. The legislation permits states to adopt the law once only. Once the state has adopted the law, it is dropped from the database. Figure 2 shows the Kaplan-Meier failure estimate considering the number of states at risk of adopting the law. The rate of adoption followed an unstable and fragmented distribution over time. California was the first state to adopt the law in 1995. Between 1996 and 2001, for six years, no state adopted the law. The second adoption occurred in 2002. From this period onward, a diffusion process takes place and the number of adoptions increases. After 2009, however, the adoptions stopped. The policy was adopted by more than 24 of the 48 American states included in the study. Hawaii and Alaska were left out because it is common in the literature to focus on the 48 contiguous states.

12 - In Weibull distribution a positive signal indicates that the likelihood of survival increases and consequently that the risk of failure decreases (Colosimo \& Giolo, 2006). 
Figure 2: Cumulative distribution of failure times for Statewide Smoking Ban, U.S., 19952010

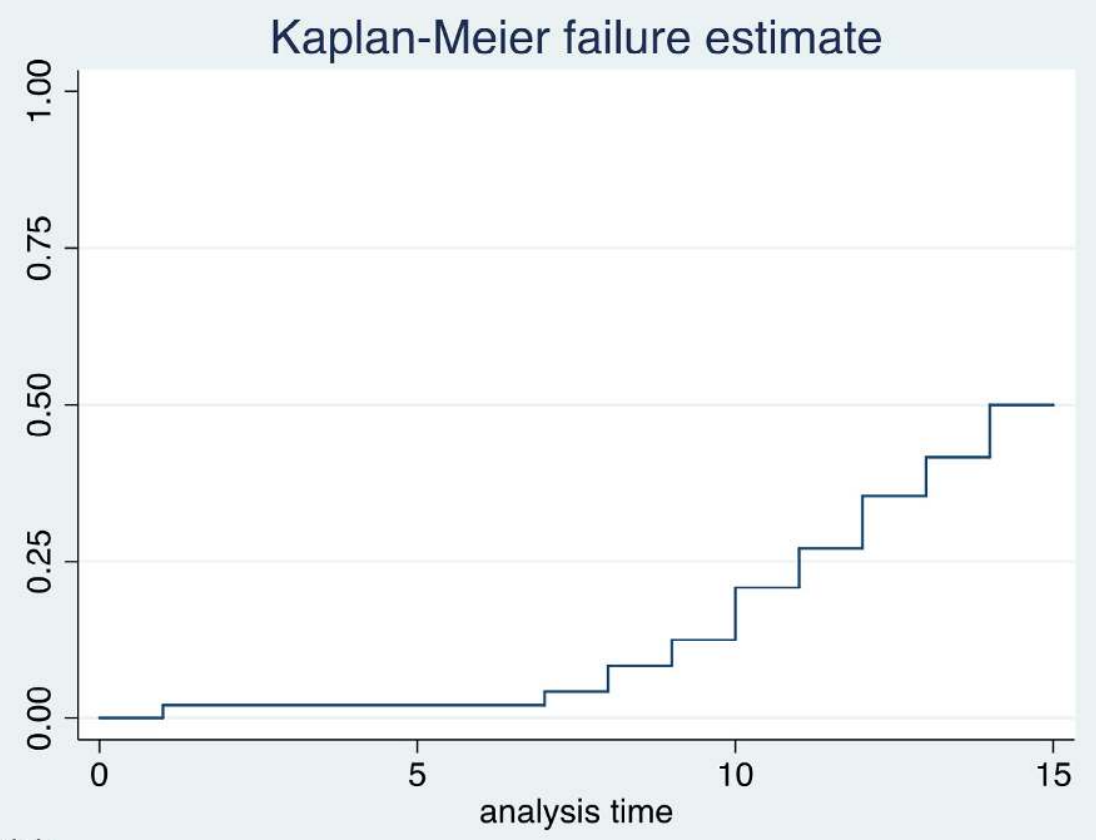

Number at risk

48

47

42

24

\section{Source: The Author}

The data were obtained from multiple sources. The principal source was the Harvard Dataverse: State Policy Innovation Diffusion (Boehmke et al, 2018). Other sources included: Replication data for Political competition in Legislative Elections (Polborn, 2018); Comparative Agendas Project ${ }^{13}$; State ideology Data (Berry et al, 2010); National Conference of State Legislatures; and U.S. Census Bureau, Population Division. On the anti-smoking policy, I replicate data constructed by Shipan and Volden (2006) from: the Centers for Disease Control and Prevention, Goldstein and Bearman (1996); and the National Cancer Institute, State Cancer Legislative Database Program.

To measure the effect of independent variables on the policy diffusion, I control for a mixture of internal and external determinants and for structural factors.

Dependent variable. Dichotomous variable. This is the state-year-adoption and is coded equally to 0 when the law does not pass and equally to 1 when the law passes.

Electoral year. Dichotomous variable. This calculates whether governments adopt laws in electoral years. Because political actors want to be innovative for their voters, I suppose a positive correspondence between elections and adoptions. The variable is coded as value 1 for the electoral years and as 0 otherwise. 
Partisan composition. Dichotomous variable. This reveals the partisan composition of state legislatures. Similar to the hypothesis that points out that the Democratic Party is more likely to adopt anti-smoking policies, I expect that, when both legislative chambers have Democratic majorities, the law passes. The variable receives 1 for the states with Democratic majorities and 0 when both chambers have Republican majorities, or are divided.

Government ideology. Continuous variable. This is an index measuring state government ideology between 1960 and 2017. The scale varies from 0 (most conservative) to 100 (most liberal) and defines the ideology of a state government. It uses a weighted average of the ideological position of Democratic and Republican delegations in the state and senate houses and also of the governor (Berry et al., 1998). A negative correlation is expected between conservative governments and the adoption of restrictive anti-tobacco policies.

Citizen ideology. Continuous variable. Similar to government ideology, this variable measures a scale from 0 (most conservative) to 100 (most liberal). The ideological position of citizens matters because it produces political pressures in favor of smoke-free areas and places. So I expect a positive association between the index and adoption of the law.

Percent of adult smokers. Numeric variable. This variable counts the percentage of adults in the state who smoke. Like citizen ideology, the number of adult smokers probably produces political pressures and I expect a negative coefficient.

Preview adoption of health policies. Numeric variable. It counts the percentage of health policies adopted for each state between 1990 and 2017. The background of government preferences, in terms of stock of health policies, probably triggers governmental restrictions on smoking. So I might expect a positive link with anti-smoking laws.

Government building restrictions. Dichotomous variable. This shows whether states have already adopted coercive state laws to restrict smoking. If the state has adopted the law, then it is assigned a value of 1 , and if the state did not adopt, it is set equal to 0 . For this variable, I would suppose a positive coefficient.

Regarding health organization lobbyists, like Brazil, U.S. states differ in institutional and social levels, economies, and size. It is, then, essential to control for the differences between units. The control variable is the presence of pro-health lobbies. Following Shipan's \& Volden's (2006) expectations, I expect states with active health organizations to be more likely to generate antismoking legislation.

\section{Determinants of Metropolitan Region in Brazil}

I present the results of the Weibull distribution in Table 1. As pointed out before, I had expectations of a mix of internal and structural determinants to explain the metropolitan-region diffusion. I find strong support for the majority of variables, which suggests that the explanatory model is well adjusted for testing causal hypotheses. There is strong empirical evidence that political factors lead to more state adoptions. The coefficient on electoral year is highly significant and the sign is negative, indicating that it increases the likelihood of adopting the law. The high coefficient and negative sign suggest that states pay more attention to urban policies at a specified time. The result indicates that the median time for adoption is 30 percent longer in years without state elections. Government ideological preferences also appear to be positively associated with metropolitan regions. The variable is set to take a value between -1 (extreme left) and +1 (extreme right). The coefficient shows that the probability of adopting the law increases to the right side. The median time of adoption is 42 percent less for the parties on the right. Ex- 
tension of the electoral coalition also influences the decision to adopt or not to adopt the policy. It is statistically distinct from other variables because it has a positive sign. I hypothesized that the higher the extension of an electoral coalition, the higher the probability of adopting metropolitan regions. However, I find that it increases the likelihood of survival and consequently increases the time until the occurrence of the adoption event. Thus, the median time for adopting the policy increases by five percent for each unit into an electoral coalition. With relation to the number of effective parties, the coefficient shows that this does not affect the phenomena. Considering the two last statistical results, I suppose that the government's political control on legislation is not the decisive factor in explaining the spread effect of the recent urban agenda in Brazil. Once governors and legislators can individually propose metropolitan regional laws, it seems that the number of parties and the highest (not the lowest) distribution of votes increases the chances of passing the law. While this indicates more legislative participation, it implicates more political negotiation. For this reason, I believe that more research is needed for better comprehension of the case.

Concerning structural variables, the principal hypothesis is confirmed. States with regional capitals included among their law's proposals were more likely to adopt new metropolitan regions. The variable is highly significant with a negative sign and tightly affects the probability of adopting the law. States that did not include regional capitals in their proposals had an increase of 48 percent in terms of median time for approving the law.

The control variable shows that there is no impact on the dependent variable, which suggests that states pay less attention to the size of the population when deciding to adopt metropolitan regions.

Table 1: Determinants of the Diffusion of Metropolitan Regions in Brazil (1991-2018)

\begin{tabular}{|l|l|}
\hline \multicolumn{2}{|l|}{ Model 1: Metropolitan Regions (Weibull distribution) } \\
\hline (Intercept) & $\begin{array}{l}8,57407 \\
(0,50348)\end{array}$ \\
\hline Electoral year & $-0,25633^{* * *}$ \\
& $(0,07207)$ \\
\hline Government ideology & $-0,35211^{* *}$ \\
& $(0,16229)$ \\
\hline Extension of electoral coalition & $0,04731^{* * *}$ \\
& $(0,00833)$ \\
\hline Number of effective parties & 0,00916 \\
& $(0,01895)$ \\
\hline Regional capital & $-0,39503^{* * *}$ \\
& $(0,10680)$ \\
\hline Log (municipal metropolitan population) & $-0,01618$ \\
& $(0,11240)$ \\
\hline Log (scale) & $-2,14797$ \\
& $(0,11240)$ \\
\hline
\end{tabular}

Notes: Standard error in parentheses; ${ }^{* * *} \mathrm{p}<0.01,{ }^{* *} \mathrm{p}<0.05,{ }^{*} \mathrm{p}<0.1$.

Source: The Author 


\section{Determinants of Statewide Smoking Ban in the U.S.}

In Table 2, I present the results of event history analysis. The expectation is that a combination of variables related to internal and structural determinants explain the spread of statewide smoking bans across American states. The analysis illustrates that there is support for a mix of variables, showing that the statistical model fits well in theoretical and methodological terms. Regarding coefficients to political factors, there is minimal support for the three tested hypotheses, which indicates that other determinants influenced the policymakers. Only the electoral year influences the states positively. This is highly significant and the sign is positive. In electoral years the odds of adopting the law are 16 times higher than in non-election years. Therefore, according to coefficients shown in Table 2, states are not likely to be influenced by the roles of partisan composition or government ideology. However, for complementary internal determinants, I find evidence that the characteristics of populations do matter for anti-tobacco policy diffusion. The hypothesis that affirms that states with more liberal citizens are more likely to adopt the law is confirmed. The probability of adopting the statewide smoking-ban policy increases by eight percent for states with a high index of liberal citizens, which suggests that the ideological position of citizens yields political pressures and new state legislation. The percentage of smokers is also consistent with my expectation. I hypothesized that a high percentage of adult smokers would produce political pressures to reject the law, or to spend more time passing it. For this reason, I expected a negative coefficient. The regression demonstrates that the coefficient is highly significant, and the sign is negative. Its odds of a state with a high percentual of adult smokers adopting the law decrease by 41 percent. So the analyses suggest that social organizations and market companies, directly and indirectly, influence legislators. As previously demonstrated by Pacheco and Boushey (2014) and McCann et al. (2015), the effect of smoking is associated with the state population's health, economy, and the state's health budget.

Preview adoption of health policies and government building restrictions were defined as structural variables with the potential to affect the choice of governments. To be specific, I expect a positive correlation between the stock of health public policies and innovations in the health area. The coefficient reports a positive result and suggests that there are different groups for state innovativeness in terms of health across American states. Data from Harvard Dataverse (Boehmke and Skinner, 2012b) show that states such as New Jersey, California, Illinois, Maine, Maryland, and Rhode Island are more innovative than Michigan, South Carolina, Pennsylvania, and Alabama. While the first group of states adopted 85 percent of all health diffused policies between the 1990s and 2000s, the second group adopted only 30 percent of these policies. In sum, states with more health policies have a five percent greater chance of adopting the law. I also expected a positive effect on the states with preview restriction laws in terms of advancing the agenda against the tobacco industry. As shown in Table 2, the variable is consistently significant with a positive sign. The hazard ratio reveals that states which had previously adopted government building restrictions have a five times greater risk of adopting the new anti-smoking law than do other states.

Health organizations' lobbyists were defined as a control variable and did not influence state legislative action. Previous policy diffusion studies (Shipan \& Volden, 2006; Pacheco \& Boushey, 2014; McCann et al., 2015) of state legislation against smoke-free areas raise some considerations. They confirm that the rate of adoption of the new policy depends on the presence of critical variables such as the time, the features and attitudes of the population, and the system in which the innovation takes place. I believe that this study reinforces these postulates. 
Table 2: Determinants of the Diffusion of Statewide Smoking Ban

in the U.S. (1995-2010)

\begin{tabular}{|l|l|}
\hline \multicolumn{2}{|l|}{ Model 2: Statewide smoking ban (Cox regression) } \\
\hline Electoral year & $\begin{array}{l}0,008^{* *} \\
(17,5433)\end{array}$ \\
\hline Partisan composition & 0,935 \\
& $(0,86983)$ \\
\hline Government ideology & 0,382 \\
& $-(0,28540)$ \\
\hline Citizen ideology & $0,001^{* *}$ \\
\hline Percentage of smokers & $(0,02590)$ \\
\hline Preview adoption of health policies & $0,000^{* * *}$ \\
& $-(0,06180)$ \\
\hline Government building restrictions & $0,016^{*}$ \\
& $(0,02373)$ \\
\hline Health organizations' lobbyists & $0,026^{*}$ \\
& $(3,88355)$ \\
\hline
\end{tabular}

Notes: Standard error in parentheses: ${ }^{* * *} \mathrm{p}<0.01,{ }^{* *} \mathrm{p}<0.05,{ }^{*} \mathrm{p}<0.1$.

Source: The Author

\section{Social and Political context related to adoption}

The analysis shows that the diffusion of two policies has been established in the political systems in both countries. However, as pointed out before, the states did not pass the laws during the earliest years, which means that the attributes of the policies themselves were not determinant in driving the adoption.

The policy diffusion process may also be observed in social and political differences across states. For instance, Araújo et al (2016) analyzed the metropolitan agenda in Brazil and suggested that the phenomenon was explained by path dependency and by the characteristics of each state's political context. Using the same perspective, Souza (2003) highlights that the state government's lack of institutional capacity converted the issue into a local governance problem. This shows that the adoption of the new legislation was very different between states. Some states enacted laws for a small population, or without a regional capital, with economic and social influence from other cities. This is the case with Alagoas and Paraíba, two small states that adopted nine and 12 new metropolitan regions, respectively. In other states, the role of bureaucracy was key to the quality of the formulation. In Minas Gerais and the Rio Grande do Sul, two of the richest states in Brazil, one metropolitan region was adopted for each state. The first group of adopters was influenced by a positive agenda in terms of inter-municipal cooperation and applications for federal and international grants. The other state actors, such as 
epistemic communities and social activists, became important in terms of agenda-setting after the 2010s, but with a moderate effect. In this sense, the potential of social benefits ${ }^{14}$ was less influential in the diffusion process.

The spread of policies also depends on the reputation of the innovator and the role of the social system. Despite the gap between the earliest and subsequent adoptions, the experience of California influenced other states through the dissemination of the idea of using the social network to formulate solutions to a persistent health problem. As Boehmke and Skinner (2012a) have shown, California is the top innovator. They measured differences in policy innovativeness across the American states and found that California's policies were frequently adopted by other states. Data from SPIS (Boehmke \& Skinner, 2012b) also give a bell-shaped visualization, placing California as a seeder state when considering areas such as law and crime, health, and education. As pointed out in the literature, the conditions for change in terms of policy spread would be related to political incentives and positive social perception. The local debate over tobacco control began in the early 1980s when the public health community accepted the evidence that second-hand smoke was harmful to society. At the beginning of the 1990s, the image of a solution was idealized after strong scientific evidence. The national and state environmental protection agencies issued a report declaring second-hand smoke as carcinogenic to humans and the Tobacco Survey found that smoke-free workplaces were less exposed compared with other workers (Borland et al., 1992). As a result, local advocates, such as state-level offices of the American Heart Association, the American Cancer Society, the American Lung Association, and local politicians were active in disseminating the idea of protecting people against illnesses such as lung cancer. After this initiative, hundreds of municipalities implemented smoke-free workplace ordinances. As a spillover effect, the laws went from the micro to the macro system and the state law became effective on January 1, 1995.

\section{Conclusion}

This study is the first to tentatively understand how policy diffusion takes place in two federative countries with different backgrounds in terms of emulation of innovation. I explored two original databases on urban and health policies from the 1990s and 2000s to identify the factors that affect multiple agenda-setting in Brazil and the U.S. The results confirm some conventional concepts, but bring other, unconventional, empirical, theoretical, and methodological perspectives. First, it seems that the phenomena are out of place. Empirically, I have shown that, like the U.S., Brazilian state governments experienced the adoption of institutional innovation among themselves. More specifically, in a federation where subnational governments are economically dependent on the central government, I show that policy diffusion can take a horizontal direction. This may occur through a certain uncoordinated interdependence (Elkins \& Simmons, 2005). Depending on the policy, the central government does not always matter in terms of explaining the adoption of policies. Second, beyond political variables, structural factors play a crucial role in explaining political behavior and, consequently, the motivations for adopting or not adopting a law. While, in Brazil, governmental ideology strongly influenced the passage of laws, in the U.S., this did not appear to be essential. Rather, in the U.S, citizen ideology and preview health policies drive the diffusion. I find a similar condition, that of electoral year, positively affects the diffusion of policies. This result is especially intriguing in the Brazilian case because there is a federal law limiting the creation of new policies in election

14 - The implementation of specific laws or norms between metropolitan municipalities to establish: i) low phone tariffs; ii) standardization of wages; and iii) allocation of habitational resources (Araújo et al. 
years. Empirical results bring further theoretical implications, namely the magnitude of policy diffusion. For instance, 59 percent of new metropolitan regions were adopted by four states, and 71 percent of adoptions of statewide smoking ban took place in the more innovative states. These data reveal that the waves of diffusion may engender different pressures in the political system. While in Brazil, leader states, such as Rio de Janeiro, Rio Grande do Sul, and Minas Gerais, did not influence other states, in the U.S., innovative states such as Delaware, Rhode Island, and California indirectly seeded the regions and affected the rate at which the policy spread. So it is crucial in terms of mapping the process and conducting qualitative analysis for an appropriate comprehension of specific geographic clusters. In sum, I find that the adoption of the two policies was strongly driven by internal determinants and by moderate and robust interdependence among Brazilian and American states, respectively.

Concerning methodological findings, in some of its points this paper contributes to future research. Scholars should consider applying a framework for comparative analyses combining different countries, policies, and statistical models. State-to-state diffusion is "almost" an American agenda. Setting the Brazil case as an example, I show that a decentralized federation has experienced similar events to those typically occurring in American states. It is crucial to renew the policy diffusion literature in terms of examining validity and the effect of variables either in a multiparty system or in a country without slack resources (Walker, 1969). Federalist countries, such as Argentina, Mexico, Colombia, and Germany, have experienced the policy diffusion process with the research appearing to have been done from a comparative perspective (Porto de Oliveira and Faria, 2017; Hassenteufel et al., 2017; Kuhlmann et al., 2019; Abel, 2019). As indicated by Rogers (1995), the rate of adoption of innovation is influenced by: i) perceived attributes of innovation; ii) types of innovation-decision; iii) communication channels; iv) the nature of social systems; and v) the extent of the change agent's promotion efforts. Future research can mix these categories with internal and external determinants to disentangle them and to explain which variables count in terms of the policy diffusion process in different areas and countries.

A future study might also investigate the role of central governments, in vertical diffusion to subnational governments, in testing the variation of adoption of innovation among rich and poor states. Another study might explore how policy diffusion is affected by differences in government institutional capacity in terms of professionalism in state legislatures and bureaucracies. Unfortunately, studies of diffusion comparing decentralized federations remain rare. A possible path that may represent an advance in this area is the collection of data from similar policies among a group of selected countries. Innovation in urban and health areas looks a likely starting-point. Thus, this paper sheds some light on theoretical and methodological questions. What are the differences and similarities between policy diffusion in the U.S. and in other countries? How can we measure and compare aspects of federalism which impact on intergovernmental competition? The answers to these questions are complex, but they may represent a step forward for the construction of an international database that would permit us to conduct longitudinal studies. This study suggests that it is valid to test similar and rival hypotheses conventionally and this should be widely explored by American scholars. I propose that scholars look, from a comparative perspective, at additional internal and external determinants, so that conclusion can illuminate undiscovered, and seemingly unrelated, connections between countries. Recently, a group of comparative researchers has been moving in this direction, exploring how policies have spread among Latin American countries (Faria, 2016) and focusing on the dissemination of regulatory agencies (Jordana, 2016). Following these steps, future research may make the findings more generalizable. 


\section{Bibliography}

Abel, D. (2019). The diffusion of climate policies among German municipalities. Journal of Public Policy, 41(1) 1-26.

Abrucio, L. F. (1998). Os barões da federação: os governadores e a redemocratização brasileira. São Paulo: Editora Hucitec.

Abrucio, F., Sano, H., \& Segatto, C. (2016). Cooperação interestadual: o papel do Consad e do Consed na disseminação de reformas e políticas públicas. In C. A. P. de Faria, D. B. Coêlho, S. J. da Silva (Eds.). Difusão de Políticas Públicas (pp. 103-131). São Paulo: Ed. da UFABC

Araújo, S. V. G.; Fernandes, A. S. A.; Coêlho, D. B. (2016). Does Metropolitan Areas Management Matter in Brazil? Elements of a Complex Issue. disP The Planning Review, 52 (2), 17-25.

Arretche, M. (2004). Federalismo e políticas sociais no Brasil: problemas de coordenação e autonomia. São Paulo em Perspectiva, 18(2),17-26.

Baybeck, B.. Berry, W. D. \& Siegel, D. A. (2011). A Strategic Theory of Policy Diffusion via Intergovernmental Competition. The Journal of Politics, 73(1), 232-247.

Balla, S. J. (2001). Interstate Professional Associations and the Diffusion of Policy Innovations. American Politics Research, 29(3), 221-245.

Berry, F. S. \& Berry, W. D. (1990). State Lottery. Adoptions as Policy Innovations: An Event History Analysis. American Political Science Review, 84(2), 395-415.

Berry, F. S., \& Berry, W. D. (1992). Tax Innovation in the States: Capitalizing on Political Opportunity. American Journal of Political Science, 36(3), 715-742.

Berry, F. S., (1994). Sizing Up State Policy Innovation Research. Policy Studies Journal, 22(3), 442456.

Berry, W. D., Ringquist, E. J., Fording, R. C., \& Hanson, R. L. (1998). Measuring Citizen and Government Ideology in the American States, 1960-93. American Journal of Political Science, 42(1), 327. https://doi.org/10.2307/2991759

Berry, W. D., Ringquist, E. J., Fording, R. C., \& Hanson, R. L. (2007). The Measurement and Stability of State Citizen Ideology. State Politics \& Policy Quarterly, 7(2), 111-132. https://doi.org/10.1177/153244000700700201

Berry, W. D., Ringquist, E. J., Fording, R. C., \& Hanson, R. L., \& Klarner, C. (2010). Measuring Citizen and Government Ideology in the American States: A Re-appraisal. State Politics and Policy Quarterly, 10(2), 117-135.

Boehmke, F. J., \& Witmer, R. (2004). Disentangling Diffusion: The Effects of Social Learning and Economic Competition on State Policy Innovation and Expansion. Political Research Quarterly, 57(1), 39-51.

Boehmke, F. J., \& Skinner, P. (2012a). State Policy Innovativeness Revisited. State Politics \& Policy Quarterly, 12(3), 303-329.

https://doi.org/10.1177/1532440012438890

Boehmke, F. J., \& Skinner, P. (2012b). State Policy Innovativeness Scores V1.1. Harvard Dataverse V4. Retrieved from:

https://dataverse.harvard.edu/dataset.xhtml?persistentId=hdl:1902.1/18507hdl.handle. net/1902.1/18507 
Boehmke, F. J., Brockway, M., Desmarais, B., Harden, J. J., LaCombe, S., Linder, F., \& Wallach, H. (2018). State Policy Innovation and Diffusion (SPID) Database v1.2 [Data set]. Harvard Dataverse. https://doi.org/10.7910/DVN/CVYSR7

Borland R., Pierce J. P., Burns D. M., Gilpin E., Johnson M., \& Bal D. (1992). Protection From Environmental Tobacco Smoke in California: The Case for a Smoke-Free Workplace. JAMA, 268(6):749752.

Boushey, G. (2010). Policy Diffusion Dynamics in America. Cambridge: Cambridge University Press.

Boushey, G. (2014). Electoral Competition and the Diffusion of Innovations. Shambaugh Conference on New Frontiers in Policy Diffusion. University of Iowa, March 13-15.

Box-Steffensmeier, J. M., \& Jones, B. S. (1997). Time is of the Essence: Event History Models in Political Science. American Journal of Political Science, 41(4), 1414-1461.

Box-Steffensmeier, J. M. (2007). Event History Modeling. A guide for social scientists. Cambridge: Cambridge Univ. Press.

Butler, D. M., \& Pereira, M. M. (2018). TRENDS: How Does Partisanship Influence Policy Diffusion? Political Research Quarterly, 71(4), 801-812.

Caughey, D., Warshaw, C., \& Xu, Y. (2017). Incremental Democracy: The Policy Effects of Partisan Control of State Government. The Journal of Politics, 79(4), 1342-1358. https://doi.org/10.1086/692669

Cleves, M. A., Gould, W. W., \& Marchenko, Y. V. (2008). An Introduction to Survival Analysis Using Stata. 2nd ed. College Station: Stata Press.

Clouse, J. G. (2019). U.S. State Constitutions Dataset, 1776-2017 (Feb 2019 Version).

Coêlho, D. B. (2012a). Political Competition and the Diffusion of Conditional Cash Transfers in Brazil. Brazilian Political Science Review, 6(2), 56-87.

Coêlho, D. B. (2012b). Brazil: Basic Income - A New Model of Innovation Diffusion. In M. C. Murray \& C. Pateman (Eds.), Basic Income Worldwide (pp. 59-80). London: Palgrave Macmillan UK. https://doi.org/10.1057/9781137265227_4

Coêlho, D. B., Cavalcante, P., \& Turgeon, M. (2016). Mecanismos de difusão de políticas sociais no Brasil: Uma análise do Programa Saúde da Família. Revista de Sociologia e Política, 24(58), 145-165. https://doi.org/10.1590/1678-987316245807

Collier, D., \& Messick, R. E. (1975). Prerequisites versus Diffusion: Testing Alternative Explanations of Social Security Adoption. The American Political Science Review, 69(4),1299-1315.

Colosimo, E. A. \& Giolo, S. R. (2006). Análise de Sobrevivência Aplicada. 1st ed. São Paulo: Edgard Blucher.

Couto, C., \& Absher-Bellon, G. (2018). Imitação ou coerção?. Constituições estaduais e centralização federativa no Brasil. Revista de Administração. Pública, 52(2), 321-344.

Dahl, R. (1989). Um prefácio à teoria democrática. Rio de Janeiro: Jorge Zahar.

Elkins, Z.., \& Simmons, B. ( 2005). On Waves, Clusters, and Diffusion: A Conceptual Framework. Annals of the American Academy of Political and Social Science, 598(1), 33-51.

Farah, M. (2008 $)$. Disseminação de políticas públicas e programas governamentais no nível subnacional de governo. Revista Administração em Diálogo, 10(2), 69-89. 
Farah, M. (2008b). Disseminação de inovações e políticas públicas e espaço local. Organizações e Sociedades, 15(45), 107-126.

Faria, C. A. P. de. (2016). A difusão de políticas sociais como estratégia de inserção internacional: Brasil e Venezuela comparados. In C. A . P de Faria, D. B Coêlho \& S. J. da Silva (Eds.), Difusão de Políticas Públicas (pp. 315-360). São Paulo: Ed. da UFABC.

Fernandes, A. S. A., Araújo, S. M., \& Coêlho, D. B. 2019. The diffusion of metropolitan regions in Brazil post-1988: genesis and perspectives. 4th International Conference on Public Policy (ICPP4), Montréal, June 26-28.

Gilardi, F. (2010). Who Learns from What in Policy Diffusion Processes? American Journal of Political Science, 54(3), 650-666.

Gilardi, F., \& Wasserfallen, F. (2019). The politics of policy diffusion. European Journal of Political Research, 58(4), 1245-1256.

https://doi.org/10.1111/1475-6765.12326

Goldstein, A. O., \& Bearman, N. S. (1996). State Tobacco Lobbyists and Organizations in the United States: Crossed Lines. American Journal of Public Health, 86(8):1137-1142.

Golosov, G. (2010). The Effective Number of Parties: A New Approach. Party Politics 16(2), 171-192.

Graham, E. R., Shipan, C. R., \& Volden, C. (2013). The Diffusion of Policy Diffusion Research in Political Science. British Journal of Political Science, 43(3), 673-701.

Gray, V. (1973). Innovation in the States: A Diffusion Study. American Political Science Review, 67(11), 74-85.

Hassenteufel, P., Benamouzig, D., Minonzio, J., \& Robelet, M. (2017). Policy Diffusion and Translation: The Case of Evidence-based Health Agencies in Europe. Novos estudos CEBRAP, 36(1), 77-96.

Hinkle, R. K. (2015). Into the Words: Using Statutory Text to Explore the Impact of Federal Courts on State Policy Diffusion. American Journal of Political Science, 59(4), 1002-1021.

IBGE. (2018). Regiões de Influências das Cidades. Retrieved from:

https://www.ibge.gov.br/geociencias/cartas-e-mapas/redes-geograficas/15798-regioes-de-influencia-das-cidades.html

Kiewiet, D. R., \& McCubbins, M. D. (1985). Congressional Appropriations and the Electoral Connection. The Journal of Politics, 47(1), 59-82.

Jordana, J. (2016). A difusão das agências reguladoras na América Latina: uma perspectiva institucional. In C. A. P. de Faria, D. B. Coêlho, S. J. da Silva (Eds.). Difusão de Políticas Públicas (pp. 211236). São Paulo: Ed. da UFABC

Karch, A. (2007). Democratic Laboratories: Policy Diffusion among the American States. Ann Arbor, MI: University of Michigan Press.

Karch, A. (2012). Vertical Diffusion and the Policy-Making Process: The Politics of Embryonic Stem Cell Research. Political Research Quarterly, 65(1), 48-61.

Keefer, P., \& Khemani, S. (2005). Democracy, Public Expenditures, and the Poor: Understanding Political Incentives for Providing Public Services. The World Bank Research Observer, 20(1), 1-27.

Keefer, P., \& Khemani, S. (2003). Why do the poor receive poor services? Economic and Political Weekly, 39(9), 935-943.

Kuhlmann, J., González de Reufels, D., Schlichte, K., \& Nullmeier, F. (2019). How social policy travels: A refined model of diffusion. Global Social Policy, 20(1), 80-96. 
McCann, P. J. C., Shipan, C. R., \& Volden, C. (2015). Top-Down Federalism: State Policy Responses to National Government Discussions. Publius: The Journal of Federalism, 45(4), 495-525.

Makse, T., \& Volden, G. (2011). The Role of Policy Attributes in the Diffusion of Innovations. Journal of Politics, 73(1), 108-124.

May, P. J. (1992). Policy Learning and Failure. Journal of Public Policy, 12(4), 331-354.

Menzel, D. C., \& Feller, I. (1977). Leadership and Interaction Patterns in the Diffusion of Innovations among the American States. Western Political Quarterly, 30(4), 528-536.

Meseguer, C., \& Gilardi, F. (2009). What is new in the study of policy diffusion? Review of International Political Economy, 16(3), 527-543.

Mintrom, M. (1997a). The State-Local Nexus in Policy Innovation Diffusion: The Case of School Choice. Publius: The Journal of Federalism, 27(3), 41-59.

Mintrom, M. (1997b). Policy Entrepreneurs and the Diffusion of Innovation. American Journal of Political Science, 41(3), 738-770.

Mintrom, M., \& Vergari, S. (1998). Policy Networks and Innovation Diffusion: The Case of State Education Reforms. Journal of Politics, 60(1), 126-148.

Mooney, C. Z. (2001). Modeling regional effects on state policy diffusion. Political Research Quarterly, 54(1), 103-124.

Pacheco, J. (2012). The Social Contagion Model: Exploring the Role of Public Opinion on the Diffusion of Antismoking Legislation across the American States. Journal of Politics, 74(1),187-202.

Pacheco J., \& Boushey, G. (2014). Public health and agenda setting: determinants of state attention to tobacco and vaccines. Journal of Health Politics, Health and Policy and Law, 39(3), 565-589.

Palotti, P., Pereira, C., \& Camões, M. (2016). A adoção da carreira de gestor governamental no Brasil: há um processo de difusão em andamento? In C. A. P. de Faria, D. B. Coêlho, S. J. da Silva (Eds.). Difusão de Políticas Públicas (pp. 133-155). São Paulo: Ed. da UFABC

Polborn, M.(2018). Replication Datafor: Political Competitionin LegislativeElections. Retrievedfrom: https://dataverse.harvard.edu/dataset.xhtml;jsessionid=c53381c9a73aac9ec7d0332fce91?persist entId=doi\%3A10.7910\%2FDVN\%2FSNW8PV\&version=\&q=\&fileTypeGroupFacet=\&fileAccess=\&f ileSortField=size

Porto de Oliveira, O. (2016). Embaixadores da Participação: A difusão internacional do Orçamento Participativo a partir do Brasil. 1st ed. São Paulo: Annablume.

Porto de Oliveira, O., \& Faria, C. A. P. de (2017). Policy transfer, diffusion, and circulation: Research Traditions and the State of the Discipline in Brazil. Novos estudos CEBRAP, 36(1), 13-32.

Rogers, E. M. (1995). The diffusion of innovations. New York, NY: Free Press.

Segatto, C. (2018). Policy diffusion in subnational governments: state-local relationships in the Brazilian education policy. Regional \& Federal Studies, 28(1), 79-100.

Shipan, C. R., \& Volden, C. (2006). Bottom-up Federalism: The Diffusion of Antismoking Policies from U.S. Cities to States. American Journal of Political Science, 50(4), 825-843.

Shipan, C. R., \& Volden, C. (2008). The Mechanisms of Policy Diffusion. American Journal of Political Science, 52(4), 840-857.

Shipan, C. R., \& Volden, C. (2012). Policy Diffusion: Seven Lessons for Scholars and Practitioners. Public Administration Review, 72(6), 788-796. 
Strang, D. (1991). Adding social structure to diffusion models: An event history framework. Sociological Methods and Research, 19(3), 324-353.

Strebel, Felix. (2011). Inter-governmental Institutions as Pro- moters of Energy Policy Diffusion in a Federal Setting. Energy Policy, 39(1), 467-476.

Sugiyama, N. B. (2007). Theories of Policy Diffusion: Social Sector Reform in Brazil. Comparative Political Studies, 41(2), 193-216.

Sugiyama, N. B. (2008). Ideology \& Social Networks: The Politics of Social Policy Diffusion in Brazil. Latin American Research Review, 43(3),82-108.

Volden, C. (2002). The Politics of Competitive Federalism: A Race to the Bottom in Welfare Benefits? American Journal of Political Science, 46(2), 352-363.

Volden, C. (2006). States as Policy Laboratories: Emulating Success in the Children's Health Insurance Program. American Journal of Political Science, 50(2), 294-312.

Volden, C., Ting, M. M., \& Carpenter, D. P. (2008). A Formal Model of Learning and Policy Diffusion. The American Political Science Review, 102(3), 319-332.

Walker, J. L. (1969). The diffusion of innovations among the American states. American Political Science Review, 63(3), 880-899.

Wampler, B. (2008). A difusão do Orçamento Participativo brasileiro: boas práticas devem ser promovidas?, Opinião Pública, 14(1), 65-95.

Zucco, C., \& P., T. (2019). Fragmentation Without Cleavages? Ideology, Policy Preferences, and Political Polarization in Brazil. Working paper, Fundação Getúlio Vargas and Univ. of Oxford.

Zucco, C., \& Power, T. (2009). Estimating Ideology of Brazilian Legislative Parties, 1990-2005: A Research Communication. Latin American Research Review, 44(1), 218-246. 